\title{
Quality assurance system for professional training of future programmers in the Ukrainian higher educational institutions
}

\author{
Kruglik V. \\ Bogdan Khmelnitsky Melitopol State Pedagogical University, Melitopol, Ukraine
}

Received: $20.12 .2018 \quad$ Accepted: 28.12 .2018

\begin{abstract}
The article raises the problem of ensuring the quality of theoretical and practical training of future software engineers for professional activities in the process of their training in institutions of higher education. The author has analyzed the provisions on the system of internal quality assurance of higher education, operating in selected domestic universities. This made it possible to identify the main activities that should be carried out in order to ensure the quality of higher education at the level of educational institutions. On this basis, and taking into account our own experience, areas of activity to ensure the quality of professional training of future software engineers have been proposed. For each of these areas, goals are defined; performers; quality indicators that are subject to adjustment; system of measures. The purpose of a systematic revision of educational programs is to ensure compliance between the content of educational programs, the forms used, the methods and means of education, the current state of the IT industry, the needs of the labor market, and the needs of students. The purpose of evaluating future software engineers is to obtain relevant information about the quality of educational activities within each discipline and educational program to identify problem areas and measures to eliminate them. The aim of ensuring the quality of the teaching staff is to form a team of competent, motivated professionals who provide training for highly qualified specialists. The purpose of practical training at enterprises is to form practical experience of future software engineers in the real production process of the IT industry. The purpose of measures to provide the necessary resources for the organization of the educational process is to create an educational environment for the effective training of future software engineers. The toolkit that is appropriate to use in the implementation of measures to ensure the quality of higher education of future software engineers (professional communications; reputation and social quality control, knowledge control system; autonomy and scientific freedom; evaluation; rating; quality audit; motivation; knowledge management; defect free concept, quality management instructions, etc.).

Key words: quality of education, future engineer-programmer, professional training, higher educational institution.
\end{abstract}

\section{Система забезпечення якості професійної підготовки майбутніх інженерів-програмістів у закладах вищої освіти України}

\author{
Круглик В. С.
}

\author{
Мелітопольський державний педагогічний університет імені Богдана Хмельницького, Мелітополь, Україна
}

\begin{abstract}
Анотація. У статті порушено проблему забезпечення якості теоретичної і практичної підготовки майбутніх інженерів-програмістів до професійної діяльності у процесі їх навчання у закладах вищої освіти. Автором проведено аналіз положень про систему внутрішнього забезпечення якості вищої освіти, що діють в окремих вітчизняних університетах. Це дозволило виділити загальні заходи, які слід здійснювати з метою забезпечення якості вищої освіти на рівні закладів освіти. На цій основі і з урахуванням власного досвіду запропоновано напрями діяльності з забезпечення якості професійної підготовки майбутніх інженерівпрограмістів. Для кожного з цих напрямів визначено мету; виконавців; показники якості, які підлягають коригуванню; система заходів. Метою систематичного перегляду освітніх програм $€$ забезпечення відповідності між змістом освітніх програм, використовуваними формами, методами і засобами навчання, сучасним станом IT-галузі, потребами ринку праці, запитами студентів. Метою оцінювання майбутніх інженерів-програмістів є отримання актуальної інформації про якість освітньої діяльності у межах кожної дисципліни та освітньої програми загалом для визначення проблемних місць і заходів щодо їх усунення.
\end{abstract}

\footnotetext{
Corresponding Author: Kruhlyk Vladyslav Serhiiovych. Tel. +38(095) 257 9204. E-mail: kryglikvlad@gmail.com Bogdan Khmelnitsky Melitopol State Pedagogical University, vul. Hetmanska, 20, Melitopol, Zaporizhzhia Region, Ukraine, 72300.

Відповідальний автор: Круглик Владислав Сергійович. Тел. +38(095) 257 9204. E-mail: kryglikvlad@gmail.com Мелітопольський державний педагогічний університет імені Богдана Хмельницького, вул. Гетьманська, 20, м. Мелітополь Запорізької обл., Україна, 72300.
} 
Метою забезпечення якості викладацького складу $€$ формування колективу компетентних, мотивованих професіоналів, які здійснюють підготовку висококваліфікованих фахівців. Метою проходження практик на підприємствах $€$ формування у майбутніх інженерів-програмістів досвіду практичної діяльності в умовах реального виробничого процесу IT-галузі. Метою заходів щодо забезпечення необхідними ресурсами для організації освітнього процесу $є$ створення освітнього середовища для ефективної підготовки майбутніх інженерів-програмістів. Визначено інструментарій, який доцільно використовувати у процесі реалізації заходів із забезпечення якості вищої освіти майбутніх інженерів-програмістів (професійні комунікації; репутація і соціальний контроль якості; система контролю знань; автономія та наукова свобода; оцінювання; рейтингування; аудит якості; мотивація; менеджмент знань; бездефектна концепція; інструкції по менеджменту якості тощо).

Ключові слова: якість освіти, майбутній інженер-програміст, професійна підготовка, заклад вищої освіти.

\title{
Система обеспечения качества профессиональной подготовки будущих инженеров-программистов в высших учебных заведениях Украины
}

Круглик В. С.

Мелитопольский государственный педагогический университет имени Богдана Хмельницкого, Мелитополь, Украина

\begin{abstract}
Аннотация. В статье поднимается проблема обеспечения качества теоретической и практической подготовки будущих инженеров-программистов к профессиональной деятельности в процессе их обучения в учреждениях высшего образования. Автором проведен анализ положений о системе внутреннего обеспечения качества высшего образования, действующих в отдельных отечественных университетах. Это позволило выделить основные мероприятия, которые следует осуществлять в целях обеспечения качества высшего образования на уровне учебных заведений. На этой основе и с учетом собственного опыта предложены направления деятельности по обеспечению качества профессиональной подготовки будущих инженеров-программистов. Для каждого из этих направлений определены цели; исполнители; показатели качества, которые подлежат корректировке; система мероприятий. Целью систематического пересмотра образовательных программ является обеспечение соответствия между содержанием образовательных программ, используемыми формами, методами и средствами обучения, современным состоянием ИТотрасли, потребностями рынка труда, запросами студентов. Целью оценивания будущих инженеровпрограммистов является получение актуальной информации о качестве образовательной деятельности в пределах каждой дисциплины и образовательной программы для определения проблемных мест и мер по их устранению. Целью обеспечения качества преподавательского состава является формирование коллектива компетентных, мотивированных профессионалов, которые осуществляют подготовку высококвалифицированных специалистов. Целью прохождения практик на предприятиях является формирование у будущих инженеров-программистов опыта практической деятельности в условиях реального производственного процесса ИТ-отрасли. Целью мероприятий по обеспечению необходимыми ресурсами для организации образовательного процесса является создание образовательной среды для эффективной подготовки будущих инженеров-программистов. Определен инструментарий, который целесообразно использовать в процессе реализации мероприятий по обеспечению качества высшего образования будущих инженеров-программистов (профессиональные коммуникации; репутация и социальный контроль качества, система контроля знаний; автономия и научная свобода; оценивание; рейтингование; аудит качества; мотивация; менеджмент знаний; бездефектная концепция, инструкции по менеджменту качества и т.д.).

Ключевые слова: качество образования, будущий инженер-программист, профессиональная подготовка, учреждение высшего образования.
\end{abstract}

\section{Bcmyn}

Забезпечення якісної теоретичної і практичної підготовки майбутніх фахівців до професійної діяльності $€$ одним з основних завдань закладів вищої освіти (3ВО). Для його вирішення необхідно реалізовувати заходи, спрямовані на забезпечення якості вищої освіти і освітньої діяльності закладів вищої освіти на державному рівні, а також на рівні закладів освіти й їх окремих підрозділів. Окрім того, слід здійснювати спеціальні заходи у межах підготовки студентів за кожною галуззю знань або спеціальністю, зміст і форми яких обумовлюються специфікою відповідних освітніх ступенів і професійних кваліфікацій.

Дослідження, спрямовані на теоретичне обгрунтування, визначення сутності та розроблення показників і заходів забезпечення якості підготовки майбутніх інженерів-програмістів на усіх рівнях (державному, регіональному, закладів освіти), здійснювали вітчизняні й іноземні науковці: В.В.Звєрєва, О. Г. Калініна, М. В. Кісіль, Г. П. Клімова, Ю. А. Конаржевський, В. Г. Кремень, Т. О. Лукіна, 
Н. М. Островерхова, В. П. Панасюк, Дж. Паррі (J. Parri), В. С. Пікельна, П. Б. Полянський, M. М. Поташник, О. І. Субетто, Л. Харві (L. Harvey), M. Чен (M. Cheng) й ін. Особливості оцінки сукупності компетенцій випускників вивчали Ю. О. Дорошенко, М. М. Поташник, П. А. Ротаєнко та ін. Дослідження, спрямовані на визначення сутності та розроблення показників і заходів щодо забезпечення якості освіти, здійснювали іноземні науковці: Инь Чон Чен (Yin Cheong Cheng) [11], P. Браун (R. Brown) [8], Кіріакос C. Цімилліс (Kyriacos C. Tsimillis) [9], П. Товей (P. Tovey) [10] та ін. Питаннями моніторингу в освітньому процесі програмістів займалися А. Василатану (A. Vasilateanu), И. Марин (I. Marin) і Б. Павало (B. Pavaloiu) [7].

Mema дослідження: визначення напрямів діяльності із забезпечення якості професійної підготовки майбутніх інженерів-програмістів у закладах вищої освіти, а також мети, виконавців, показників якості, які підлягають коригуванню, і системи заходів для кожного з них.

\section{II Матеріал і методи дослідження}

У процесі розробки системи заходів, спрямованих на забезпечення якості підготовки майбутніх інженерів-програмістів у закладах вищої освіти, нами було проаналізовано наявні у відкритому доступі положення про систему внутрішнього забезпечення якості вищої освіти Дрогобицького державного педагогічного університету імені Івана Франка [2], Запорізького національного університету [3], Харківського національного університету імені В. Н. Каразіна [4], Харківської національної академії міського господарства [5] (рис. 1).

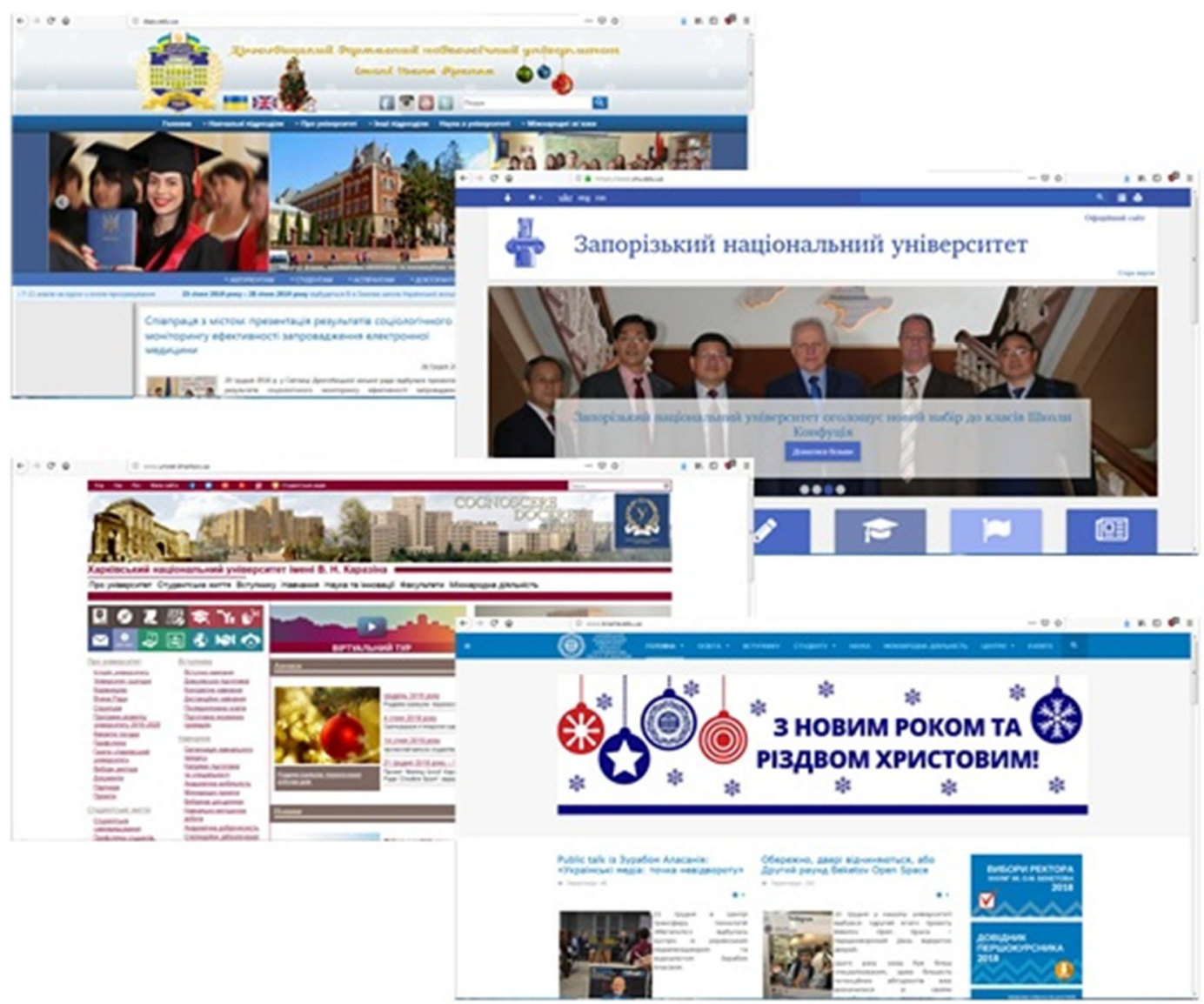

Рис. 1. Офіційні сторінки ЗВО, матеріали яких використані при розробці системи заходів забезпечення якості підготовки майбутніх спеціалістів

У цих документах визначено загальні заходи, які повинні здійснюватися з метою забезпечення якості вищої освіти на рівні навчальних закладів, зокрема [3]:

- систематичний перегляд і оновлення освітніх програм з урахуванням зовнішніх соціальних та економічних чинників; 
- оцінювання претендентів вищої освіти; якості викладацького складу шляхом застосування процедур відбору і призначення на посаду, планування діяльності та звітності, підвищення кваліфікації науково-педагогічних працівників;

- забезпечення освітнього процесу необхідними ресурсами;

- управління освітнім процесом 3 використанням відповідних інформаційних систем; забезпечення відкритого доступу до публічної інформації;

- дотримання норм академічної чесноти, запобігання та виявлення академічного плагіату.

\section{III Результати}

На основі аналізу нормативних документів, вивчення теоретичних досліджень і наявного досвіду нами була розроблена система підготовки майбутніх інженерів-програмістів (СПМІП) до професійної діяльності. Одне із завдань цієї системи полягає у створенні в закладах вищої освіти організаційнопедагогічних умов, що дозволяють здійснювати якісну профресійну підготовку майбутніх інженерівпрограмістів на рівні, відповідному сучасним стандартам IT-галузі. Всі підсистеми СПМІП (соціальна, цільова, змістовна, процесуально-діяльнісна, вихідна, результативна і прогностична) спрямовані на вирішення цього завдання.

Нами пропонуються напрями діяльності із забезпечення якості теоретичної і практичної підготовки майбутніх фрахівців:

- систематичний перегляд освітніх програм із залученням студентів та інших стейкхолдерів;

- оцінювання майбутніх інженерів-програмістів;

- забезпечення якості викладацького складу;

- проходження практик на підприємствах;

- забезпечення необхідними ресурсами для організації освітнього процесу.

Ці основні напрямки діяльності та заходи повинні конкретизуватися через систему заходів, спрямованих на забезпечення якості підготовки майбутніх фрахівців в межах кожної кафедри, спеціальності та освітнього ступеня.

\section{Систематичний перегляд освітніх програм із залученням студентів та інших стейкхолдерів.}

Мета цього напрямку: забезпечення відповідності змісту освітніх програм, а також використовуваних форм, методів і засобів навчання сучасному стану IT-галузі, потреб ринку праці регіону, країни та світу, запитам студентів; прогнозування можливих змін на найближчий час.

До реалізації заходів необхідно залучати представників всіх структурних рівнів системи керування якістю ("факультет", "кафедра", "викладач", "студент", "роботодавці"), оскільки основними стейкхолдерами $€$ студенти і роботодавці, а основними виконавцями - викладачі. Студенти і роботодавці повинні обґрунтувати свої запити і сформулювати очікувані результати підготовки.

Зауваження можуть стосуватися як в цілому освітньої програми, так і її елементів (окремих компетенцій, навчальних дисциплін, практик, навчальних та кваліфікаційних проектів, графіку навчання тощо). Відзначимо, що заходи по оновленню освітніх програм повинні носити систематичний характер, тобто їх перегляд доцільно здійснювати щорічно. 3 цією метою необхідно зробити їх настільки гнучкими, щоб можна було швидко реагувати на зміни, що відбуваються в IT-галузі та на ринку праці.

\section{Оцінювання майбутніх інженерів-програмістів.}

Мета цього напрямку: отримання актуальної інформації про якість освітньої діяльності в межах кожної дисципліни та освітньої програми в цілому для визначення проблемних місць і заходів щодо їх усунення; надання студентам інформації про їх навчальні результати в формі числових показників.

Заходи цього напрямку передбачають вдосконалення таких показників якості вищої освіти:

- позитивна мотивація студентів;

- усвідомлення студентами професіоналізму;

- якість технологій оцінювання навчальних результатів.

До реалізації заходів необхідно залучати представників структурних рівнів "фракультет", "кафедра", "викладач", "студент", а також можливо залучати "роботодавців". Викладачі, кафедри та факультет виконують заходи щодо організації процесу оцінки: розробляють графік, зміст, форми, методи оцінки; застосовують процедури оцінювання; обробляють отримані дані і повідомляють їх 
студентам; аналізують отримані дані 3 метою визначення проблем якості. Студенти виконують контрольні заходи. Роботодавців можливо залучати до розробки процедур і критеріїв оцінки.

Заходи в рамках даного напрямку роботи реалізуються на всіх етапах процесу забезпечення якості освітньої діяльності: на етапі планування якості - формулювання системи процедур оцінки; на етапі якості - застосування процедур; на етапі контролю - аналіз отриманих даних, їх повідомлення зацікавленим сторонам, визначення напрямків вдосконалення в рамках кожної дисципліни та освітньої програми в цілому.

Основні форми контрольних заходів, які застосовуються для оцінки в закладах вищої освіти:

- вхідний контроль знань;

- поточний і рубіжний контроль;

- підсумковий контроль (іспити, заліки) захист практик, курсових робіт;

- кваліфікаційний контроль (випуску іспити, захист дипломних проектів / робіт).

Забезпечення якості викладацького складу.

Мета цього напрямку: забезпечення навчального процесу компетентними, мотивованими професіоналами.

Основними виконавцями заходів є представники структурних рівнів "фракультет", "кафедра", "викладач", також можливо залучати "студентів" і "роботодавців". Роль студентів і роботодавців полягає в оцінці поточного стану якості викладацького складу.

Заходи цього напрямку мають на меті удосконалення таких показників якості вищої освіти:

- компетентність професорсько-викладацького складу;

- якість викладання;

- якість наукових досліджень;

- позитивна мотивація співробітників.

Зауважимо, що в роботі 3 викладацьким складом адміністрація повинна дотримуватися принципів, наведених в [1, с. 70]:

- заохочення повинні бути відкритими, покарання - конфіденційними;

- стимулювання пошуку перспективних рішень і обґрунтованого ризику;

- заохочення активної творчої діяльності;

- нагородження за якість, а не тільки за обсяг і швидкість виконання завдань; заохочення ефрективної командної роботи.

Спираючись на матеріали дослідження [1], пропонуємо такі заходи щодо забезпечення якості викладацького складу на кафедрах, які здійснюють підготовку майбутніх інженерів-програмістів: запрошення фахівців, які можуть активізувати інноваційну діяльність:

- запрошення до викладання (окремих лекцій або курсів) провідних викладачів вищих навчальних закладів України та інших країн, а також фахівців підприємств ІT-галузі;

- різні форми підвищення кваліффікації викладачів у закладах вищої освіти України та інших країн (стажування, тренінги, семінари, майстер-класи тощо);

- створення умов для участі викладачів у всеукраїнських та міжнародних проектах;

- залучення викладачів до проведення підвищення кваліфікації працівників інших вищих навчальних закладів і підприємств;

- організація взаємодії 3 роботодавцями (проходження викладачами стажування на підприємствах IT-галузі для ознайомлення з сучасними трендами).

\section{Проходження практик на підприємствах.}

Метою цього елементу системи забезпечення якості теоретичної і практичної підготовки $є$ формування у майбутніх інженерів-програмістів досвіду практичної діяльності в умовах реального виробничого процесу IT-галузі.

До заходів з організації проходження практик на підприємствах також залучаються представники роботодавців, фракультету, випускаючої кафедри, викладачів, студентів.

Заходи цього напрямку спрямовані на вдосконалення таких показників якості вищої освіти:

- якість студентів; позитивна мотивація студентів;

- якість технологій навчання;

- усвідомлення студентами власного просресіоналізму; 
- задоволення вимог роботодавців;

- надання старту для професійної кар'єри студентів.

На етапі планування якості необхідно визначити типи, терміни і бази проходження практики, досконало розробити інструктивні матеріали, що регулюють проходження практики та оцінки ії результатів. На етапі забезпечення якості основним заходом $€$ власне проходження практики студентами на підприємствах. На етапі контролю якості реалізують заходи з оцінювання результатів практики (в них беруть участь викладачі та представники підприємств - баз практик, а також можливо і інших підприємств ІТ-галузі), визначають недоліки і планують заходи щодо їх усунення.

\section{Забезпечення ресурсами, необхідними для організації освітнього процесу.}

Метою заходів щодо забезпечення необхідними ресурсами для організації освітнього процесу $є$ створення такого освітнього середовища, в якому можлива ефективна підготовка майбутніх інженерівпрограмістів. До таких ресурсів відноситься матеріально-технічне та навчально-методичне забезпечення освітньої діяльності.

В рамках цього напрямку доцільно застосовувати такі заходи:

- створення лабораторій на базі підприємств ІТ-галузі;

- впровадження елементів дуальної освіти;

- в разі обмежених фінансових можливостей установи вищої освіти використання підходу BYOD (з англ.: Bring Your Own Device, "Візьми Власний Пристрій (на роботу)");

- заохочення викладачів до оновлення навчально-методичних матеріалів з урахуванням сучасних IT-трендів.

\section{IV Обговорення}

Реалізація запропонованих заходів з підвищення якості професійної підготовки майбутніх інженерів-програмістів має спиратися на застосування спеціального інструментарію.

Зокрема, три групи інструментів забезпечення якості університетської освіти виділено у роботі A.I. Шийки [6, с. 110]:

1. Традиційні інструменти: професійні комунікації; незалежні перевірки; експертиза; репутація і соціальний контроль якості; дидактика вищої школи навчальний реформування; система контролю знань; автономія та наукова свобода; статистика, річні звіти і зведення даних; зовнішні інструменти оцінки якості.

2. Інструменти, близькі до середовища вищої школи: оцінка за допомогою певних систем показників; система звітності та моніторингів; оцінювання; рейтингування; акредитація; бібліометрія; студентські опитування.

3. Інструменти, трансферовані до системи вищої школи з інших областей (в основному близьких до економіки): аудит якості; сертифікація; взаємообумовлені система цілей; орієнтована на успіх система розподілу ресурсів; бенчмаркінг; мотивація; менеджмент знань; Бездефектна концепція; інструкції по менеджменту якості; гуртки якості; перманентний процес поліпшення якості.

На нашу думку, в процесі впровадження заходів щодо підвищення якості теоретичної і практичної підготовки майбутніх інженерів-програмістів на певних на рівнях слід застосовувати такі інструменти, як: профресійні комунікації; репутація і соціальний контроль якості; система контролю знань; автономія та наукова свобода; статистика, річні звіти і зведення даних; оцінювання; рейтингування; студентські опитування; аудит якості; взаємообумовлені система цілей; бенчмаркінг; мотивація; менеджмент знань; бездефректна концепція; інструкції по менеджменту якості; постійне поліпшення якості.

Заходи щодо забезпечення якості освіти та освітньої діяльності $є$ обов'язковим елементом діяльності, спрямованої на підготовку майбутніх інженерів-програмістів в закладах вищої освіти. Ці заходи повинні представляти собою цілісну динамічну систему, яка ґрунтується на принципах управління якістю, враховує все різноманіття чинників, що впливають на якість підготовки фахівців, охоплює всі рівні структури установи вищої освіти. 


\section{V Висновки}

В ході дослідження були узагальнені засоби професійної підготовки майбутніх інженерівпрограмістів до професійної діяльності. У процесі розробки системи заходів, спрямованих на забезпечення якості підготовки майбутніх інженерів-програмістів у закладах вищої освіти було проведено аналіз наявних у відкритому доступі положення про систему внутрішнього забезпечення якості вищої освіти чотирьох університетів. Було визначено основні завдання системи забезпечення якості знань і з огляду на необхідність оволодіння майбутніми інженерами-програмістами в процесі професійної підготовки декількома мовами програмування, різними методологіями, парадигмами та підходами до програмування, запропонована схема послідовності цього процесу, заснованого на принципі нарощуваних праці. Визначено основні напрямки діяльності та заходи, які повинні конкретизуватися через систему заходів, спрямованих на забезпечення якості підготовки майбутніх фахівців в межах кожної кафедри, спеціальності та освітнього ступеня. У роботі підкреслено значення позааудиторної діяльності студентів в процесі їх професійної підготовки у формах: науково-дослідницької роботи, участі в олімпіадах і конкурсах, проходження виробничої та переддипломної практики, виконання дипломної роботи. Запропоновано методику виконання групового дипломного проекту, максимально наближеного до реальної професійної діяльності, передбачає розподіл функцій між членами команди і використання інформаційних систем для контролю за ходом процесу, а також форми організації взаємодії 3 підприємствами-роботодавцями.

\section{Бібліографрічні посилання}

[1] Мутанов Г.М., Томилин А.К., Кукина Ю.Е. и др. Управление качеством в высшем учебном заведении. Усть-Каменогорск: ВКПУ, 2011.116 c.

[2] Положення про систему внутрішнього забезпечення якості вищої освіти у Дрогобицькому державному педагогічному університеті імені Івана Франка. Дрогобич: ДДПУ ім. І. Франка, 2015. 20 с. URL: http://ddpu.drohobych.net/wpcontent/uploads/2016/11/polozhennya-pro-systemu-vnutrishnogo-zabezpechennya-yakosti-vyshhoyi-osvity-u-ddpu-im.-j.franka.pdf (дата звернення 10.11.2018)

[3] Положення про систему внутрішнього забезпечення якості вищої освіти у Запорізькому національному університеті. Запоріжжя: 3НУ, 2015. 7 c. URL: https://www.znu.edu.ua/2016/polozhennya_pro_svzyavo.pdf (дата звернення 10.11.2018)

[4] [Положення про систему забезпечення якості вищої освіти (систему внутрішнього забезпечення якості) Харківського національного університету імені В.Н. Каразіна. Харків: ХHУ імені В.H. Каразіна, 2015. 16 C. URL: http:/www.univer.kharkov.ua/docs/work/yakist-osvity-polozhennya.pdf (дата звернення 10.11.2018)

[5] Положення про систему забезпечення якості освітньої діяльності та якості вищої освіти університету міського господарства імені O.M. Бекетова. Харків: ХНУМГ ім. О.M. Бекетова, 2016. 25 с. URL: http://www.kname.edu.ua/images/ Files/Normativny_Dokumenty/pologennya_sistema_yakosti_osviti.pdf (дата звернення 10.11.2018)

[6] Шийка О.І. Система забезпечення якості університетської освіти в Австрії: дис. ... канд. пед. наук: 13.00.01 / Львів, 2016. 276 с.

[7] Vasilateanu, A., Marin, I., Pavaloiu, B. (2018) Programmers' professional development monitoring system. 12th International Technology, Education and Development Conference, 5-7 March, 2018, Valencia, Spain. INTED2018 Proceedings, 9123-9126. https://doi.org/10.21125/inted.2018.2225

[8] Brown R. (2004). Quality Assurance in Higher Education. The UK Experience Since 1992. Routledge, London, UK, 224. https://doi.org/10.4324/9780203416327_chapter_7

[9] Tsimillis, Kyriacos C. (2014). Training needs to understand quality assurance. Accreditation and Quality Assurance, vol. 20 (1), 53-59. https://doi.org/10.1007/s00769-014-1092-1

[10] Tovey, Philip (2013). Quality Assurance in Continuing Professional Education. An Analysis. Routledge, London, UK, 224. https://doi.org/10.4324/9780203423684

[11] Cheng, Yin Cheong (2003). Quality assurance in education: internal, interface, and future. Education, 11 (4), $202-213$. https://doi.org/10.1108/09684880310501386

\section{References}

[1] Mutanov H.M., Tomylyn A.K., Kukyna YU.E. y dr. Upravlenye kachestvom v vysshem uchebnom zavedenyy. Ust'Kamenohorsk: VK·HTU, 2011. 116 p. [in Russian]

[2] [Polozhennya pro systemu vnutrishn'oho zabezpechennya yakosti vyshchoyi osvity u Drohobyts'komu derzhavnomu pedahohichnomu universyteti imeni Ivana Franka. Drohobych: DDPU im. I. Franka, 2015. 20 p. URL: http://ddpu.drohobych.net/wp-content/uploads/2016/11/polozhennya-pro-systemu-vnutrishnogo-zabezpechennya-yakostivyshhoyi-osvity-u-ddpu-im.-i.franka.pdf. [in Ukrainian]

[3] Polozhennya pro systemu vnutrishn'oho zabezpechennya yakosti vyshchoyi osvity u Zaporiz'komu natsional'nomu universyteti. Zaporizhzhya: ZNU, 2015. 7 p. URL: https://www.znu.edu.ua/2016/polozhennya_pro_svzyavo.pdf. [in Ukrainian]

[4] Polozhennya pro systemu zabezpechennya yakosti vyshchoyi osvity (systemu vnutrishn'oho zabezpechennya yakosti) 
Kharkivs'koho natsional'noho universytetu imeni V.N. Karazina. Kharkiv: KHNU imeni V.N. Karazina, 2015. 16 p. URL: http://www.univer.kharkov.ua/docs/work/yakist-osvity-polozhennya.pdf. [in Ukrainian]

[5] Polozhennya pro systemu zabezpechennya yakosti osvitn'oyi diyal'nosti ta yakosti vyshchoyi osvity universytetu mis'koho hospodarstva imeni O.M. Beketova. Kharkiv: KHNUMH im. O.M. Beketova, 2016. 25 p. URL: http://www.kname.edu.ua/images/Files/Normativny_Dokumenty/pologennya_sistema_yakosti_osviti.pdf. [in Ukrainian]

[6] Shyyka O.I. Systema zabezpechennya yakosti universytet s'koyi osvity v Avstriyi: dys. ... kand. ped. nauk: 13.00 .01 / L'viv, 2016. 276 p. [in Ukrainian]

[7] Vasilateanu, A., Marin, I., Pavaloiu, B. (2018) Programmers` professional development monitoring system. 12th International Technology, Education and Development Conference, 5-7 March, 2018, Valencia, Spain. INTED2018 Proceedings, 9123-9126. https://doi.org/10.21125/inted.2018.2225

[8] Brown R. (2004). Quality Assurance in Higher Education. The UK Experience Since 1992. Routledge, London, UK, 224. https://doi.org/10.4324/9780203416327_chapter_7

[9] Tsimillis, Kyriacos C. (2014). Training needs to understand quality assurance. Accreditation and Quality Assurance, vol. 20 (1), 53-59. https://doi.org/10.1007/s00769-014-1092-1

[10] Tovey, Philip (2013). Quality Assurance in Continuing Professional Education. An Analysis. Routledge, London, UK, 224. https://doi.org/10.4324/9780203423684

[11] Cheng, Yin Cheong (2003). Quality assurance in education: internal, interface, and future. Education, 11 (4), 202-213. https://doi.org/10.1108/09684880310501386

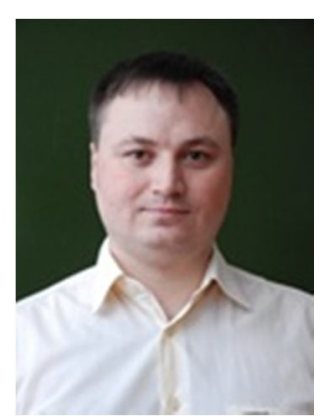

Круглик Владислав Сергійович,

д.пед.н., доцент, профессор кафедри інформатики і кібернетики,

Мелітопольський державний педагогічний університет імені Богдана Хмельницького,

вул. Гетьманська, 20, м. Мелітополь Запорізької обл., Україна, 72300.

Тел. +38(095) 257 9204. E-mail: kryglikvlad@gmail.com

Kruhlyk Vladyslav Serhiiovych,

D.Sc. (Ed.), Associate Professor, Professor of Department of Informatics and Cybernetics,

Bogdan Khmelnitsky Melitopol State Pedagogical University,

vul. Hetmanska, 20, Melitopol, Zaporizhzhia Region, Ukraine, 72300.

Tel. +38(095) 257 9204. E-mail: kryglikvlad@gmail.com

ORCID: https://orcid.org/0000-0002-5196-7241

Researcher ID: http://www.researcherid.com/rid/V-3861-2017

Scopus ID: https://www.scopus.com/authid/detail.uri?authorld=56006715100

\section{Citation (APA):}

Kruglik, V. (2018). Quality assurance system for professional training of future programmers in the Ukrainian higher educational institutions. Engineering and Educational Technologies, 6 (4), 58-65. doi: https://doi.org/10.30929/2307-9770.2018.06.04.06

\section{Цитування (ДСТУ 8302:2015):}

Круглик В. С. Система забезпечення якості професійної підготовки майбутніх інженерів-програмістів у закладах вищої освіти України / Інженерні та освітні технології. 2018. Т. 6. № 4. С. 58-65. doi: https://doi.org/10.30929/2307-9770.2018.06.04.06

.Обсяг статmі: сторінок - 8 ; умовних друк. аркушів - 0,920. 